\title{
Development of Efavirenz nanoparticle for enhanced efficiency of anti-retroviral therapy against HIV and AIDS
}

\author{
BN Vedha Hari ${ }^{*}$, K Dhevendaran $^{1}$, N Narayanan ${ }^{2}$ \\ From First International Science Symposium on HIV and Infectious Diseases (HIV SCIENCE 2012) \\ Chennai, India. 20-22 January 2012
}

\section{Background}

The FDA approved drug Efavirenz is a Non-Nucleoside Reverse Transcriptase Inhibitor (NNRTI) successful first line drug of choice in Highly Active Anti-Retroviral Therapy (HAART) for treatment of HIV and AIDS. It is poorly water soluble drug $(10 \mathrm{~g} / \mathrm{ml})$ with $40-45 \%$ of bioavailability and administered as high doses 600-800 $\mathrm{mg} /$ day. Increase in solubility can enhance bioavailability; providing reduction of dose, resistance and harmful side effects.

\section{Methods}

Efavirenz nanoparticles are developed using methacrylate polymers (Eudragit E100) by emulsion solvent evaporation method (1:0.5, 1:1, 1:2 and 2:1 ratios) and the in-vitro evaluations such as particle size, morphology, solubility changes, drug release, compatibility and cytotoxicity tests are carried out.

\section{Results}

The particle size of 99-200 nm with narrow size distribution and surface charge $(-52 \mathrm{~V})$ shows high stability. The formulation with entrapment efficiency (75-90\%) shows higher drug release profile $95-100 \%$ within 1 hour compared to $23 \%-58 \%$ of pure drug in water, $0.1 \mathrm{~N} \mathrm{HCl}$ and phosphate buffer $\mathrm{pH} 7.4$ media. The DSC, TG-DSC, powder XRD and SEM morphology results reveal that there is solid transition from crystalline structure to amorphous state, which supports the solubility enhancement. The FT-IR gives the compatibility results for drug with other excipients. The Efavirenz nanoparticles

\footnotetext{
* Correspondence: vedhahari@scbt.sastra.edu

${ }^{1}$ Department of Pharmacy, School of Chemical and Bio-Technology, SASTRA University, Thanjavur-613 401, Tamil Nadu, India

Full list of author information is available at the end of the article
}

subjected for in-vitro cytotoxicity and cell uptake studies using monocytes / macrophages (THP-1) proved better uptake (Flocytometry and Confocal microscope) of nanoparticles than free drug.

\section{Conclusion}

The solubility enhancement due to nanosizing helps in hastening the drug release and also increasing cell uptake, which helps in attaining high bioavailability with low dose of Efavirenz.

\section{Author details}

'Department of Pharmacy, School of Chemical and Bio-Technology, SASTRA University, Thanjavur-613 401, Tamil Nadu, India. ²Department of Pharmaceutics, Madras Medical College, Chennai-600001, Tamil Nadu, India.

Published: 4 May 2012

doi:10.1186/1471-2334-12-S1-P7

Cite this article as: Hari et al:: Development of Efavirenz nanoparticle for enhanced efficiency of anti-retroviral therapy against HIV and AIDS. BMC Infectious Diseases 2012 12(Suppl 1):P7.

Submit your next manuscript to BioMed Central and take full advantage of:

- Convenient online submission

- Thorough peer review

- No space constraints or color figure charges

- Immediate publication on acceptance

- Inclusion in PubMed, CAS, Scopus and Google Scholar

- Research which is freely available for redistribution

Submit your manuscript at www.biomedcentral.com/submit
() Biomed Central

\section{() Biomed Central}

(c) 2012 Hari et al; licensee BioMed Central Ltd. This is an Open Access article distributed under the terms of the Creative Commons Attribution License (http://creativecommons.org/licenses/by/2.0), which permits unrestricted use, distribution, and reproduction in any medium, provided the original work is properly cited. 